Mappemonde

Revue trimestrielle sur l'image géographique et les

formes du territoire

$126 \mid 2019$

Varia

\title{
The economic model of Chinese shopping centres in Europe
}

Le modèle économique du centre commercial chinois en Europe

El modelo económico del centro comercial chino en Europa

\section{Li Minghuan}

Translator. Ya-Han Chuang

\section{(2) OpenEdition}

\section{Journals}

\section{Electronic version}

URL: http://journals.openedition.org/mappemonde/1320

DOI: 10.4000/mappemonde.1320

ISSN: $1769-7298$

\section{Publisher}

UMR ESPACE

\section{Electronic reference}

Li Minghuan, «The economic model of Chinese shopping centres in Europe », Mappemonde [Online], 126 | 2019, Online since 01 April 2019, connection on 11 November 2019. URL : http:// journals.openedition.org/mappemonde/1320 ; DOI : 10.4000/mappemonde.1320

This text was automatically generated on 11 November 2019.

\section{(c) (i) (2)(2)}

La revue Mappemonde est mise à disposition selon les termes de la Licence Creative Commons Attribution - Pas d'Utilisation Commerciale - Partage dans les Mêmes Conditions 4.0 International. 


\title{
The economic model of Chinese shopping centres in Europe
}

\author{
Le modèle économique du centre commercial chinois en Europe \\ El modelo económico del centro comercial chino en Europa
}

Li Minghuan

Translation : Ya-Han Chuang

Original article: "Ouzhou huaren shangcheng jingji yanjiou” "“A study on Chinese malls economy in Europe"). Shijie Minzu, 2013-3, p.53-60.

Li Minghuan is Professor at the Institute of Population Studies at Jinan University in China and a consultant at the Chinese Affairs Bureau Abroad of the State Council of China. A sociologist, she has published more than sixty articles in journals in English and Chinese on the situation of Chinese migrants in Europe and on international migration policy. She has also published two books in English on these topics. The first, drawn from her doctoral research, is entitled "We Need Two Worlds: Chinese Immigrant Associations in a Western Society”, (Amsterdam University Press, 1999). The second, "Seeing transnational: how do Chinese migrants make their dreams come true" (Leuven University Press, 2013), focuses on the transnational networks of Chinese entrepreneurs in Europe.

This article is based on the project "Ouzhou huaren yanjou" ("Research on Chinese Overseas in Europe") sponsored by the National Social Science Funding of the Chinese Government (11BMZ038). This is a pioneering article written by the Chinese specialist on these issues that offers a point of view significantly different from the one commonly carried by work done from Europe.

\section{Introduction}

1 Since the beginning of the twenty-first century, due to rapid economic growth in China, the Overseas Chinese in Europe have experienced considerable transformations with 
respect to their demographic structure and economic power. These transformations are especially striking when considering the Chinese mall, a rapidly growing economic model within the European continent. The Chinese mall model has replaced such traditional economic niches as the Chinese restaurant, the textile workshop and the retail shop, bringing a new economic standard to Chinese communities in Europe in terms of scale and influence.

2 The new Chinese market differs from the traditional "Chinatown". Chinatowns are typically located in neighborhoods with high concentrations of Chinese residents. Although these exotic Chinatowns may attract tourists and locals, their principal function is to provide services for the ethnic Chinese who reside in the community. In contrast, the new Chinese markets aggregate hundreds or thousands of shops selling products made in China. Their principal business model is wholesale. Chinese markets have become important platforms of exchange for the entrepreneurs of the Chinese diaspora, as well as nodal points of circulation for Chinese products in Europe. In this sense, the Chinese markets are a site of direct encounters between overseas Chinese and the populations of their host societies; as such, the markets have become objects of attention among politicians, the media, and ordinary citizens. Whether the malls' owners realize it or not, the Chinese market has become to a degree the representation of China and made-in-China products in overseas countries. For these reasons, the Chinese market is not only an economic phenomenon, but also a crucial subject of study with theoretical and practical significance.

3 This article's analysis is based on an extensive literature review and in-depth interviews with entrepreneurs via four field studies conducted between 2011 and 2012 in France, Italy, Spain, Hungary, Russia and Romania. Besides observations in local malls and interviews with the entrepreneurs, I have enriched my understanding of the issue through discussion with local scholars and political authorities.

\section{The process of development of Chinese malls in Europe}

4 Overseas Chinese communities in Europe are characterized by a sizable proportion of new, first-generation migrants. According to the statistics made by the European Federation of Chinese Associations (Ouzhou huaqiao shetuan lianhehui), the population of the Chinese diaspora in Europe in 1950 only amounted to about 10,000 persons. It rose to 50,000 in the 1960s. In the 1970s, as European countries such as France accepted a great number of "boat people" fleeing from the war in Vietnam, the population of the Chinese diaspora in Europe rose drastically. Since then, new migrants have been continuously arriving in Europe from mainland China. According to the 2008 annual report of the European Overseas Chinese's Association (ouzhou Huaqiao huaren lianhe hui), the total population of the Chinese diaspora in Europe has reached 250,000. Today, Chinese migrants are everywhere in Europe. They have established more than 800 associations and more than 300 Chinese language schools, and they have published more than 100 journals in the Chinese language. Indeed, the Chinese diaspora in Europe - composed mainly of new, first-generation migrants who left China after 1978 - has attracted wide attention across the continent ${ }^{1}$. 
Before the end of 1980s, Chinese migrants' economic activities in Europe were mainly characterized by service work such as catering, textile fabrication, leather-goods and retail. Besides exceptional cases such as the "Tang Frères" supermarket, which has become an important enterprise at the national level, most Chinese economy models only survive in the niche economy. In East European countries, the number of Overseas Chinese is even fewer. As a result, they rarely launch economic activities outside the co-ethnic market.

6 Entering the 1990s, after the dissolution of the USSR, the social-economic structure in East European countries has produced extraordinary opportunities for the new Chinese migrants. This historical development has coincided with China's rapid economic growth, a consequence of the creativity of ordinary Chinese people that emerged after China's economic reform of 1978. As a result, the European Chinese communities' economic model has evolved. International trading has become a newly dominant model, spreading from South-Eastern Europe to the Northern and Western part of the continent. Thanks to China's productivity, overseas Chinese have established several, enormous commercial centers serving multiple functions (storage, wholesale, and retail at the same time). Thus emerged a new economic model, characterized by these large malls, managed by new Chinese migrants who sell products made in China.

7 Since their genesis in the 1990s, Chinese malls in European cities have experienced a three-step evolution.

8 The 1990s saw the emergence of the Chinese mall economy. During this period, numerous new Chinese migrants introduced low-cost Chinese products into the European market via various channels. The paths taken by these nomadic traders were diverse: several travelled to Eastern Europe and considered their practice as a "training" (liantan); some became basket vendors in Southern Europe (tilan jiaomai); and others commuted between China and Russia to sell destocked goods (daoye). The cheap and original products fabricated by local private enterprises in China found great success in Europe, especially among the lower and middle classes. Among the most successful of the earliest traders who joined the market, several rapidly opened their own wholesale shops. Driven by the effect of these "agglomeration economies", various wholesale markets of different sizes were established in European cities. The most famous examples from the 1990s include the Four Tigers' Market in Budapest, the "M" market at Piazza Vittorio in Rome, the Centro Mourario in Lisbon, the SedainePopincourt neighborhood in Paris, as well as the Cherkízovsky rýnok market in Moscow. The common characteristics of these markets include spatial concentration, with sizeable inflows of customers and high profits based on low costs of production. Their economic principle is based on the rapidity of primitive accumulation of capital. According to a successful entrepreneur in Italy, "During this period, not a single shop owner experienced a loss of profits... At that time, it was normal to sell 400-500 containers of products per year, or 10 containers per day." Many of the wealthiest Chinese entrepreneurs currently alive earned their very first capital during that period.

9 From late 1990s to 2007, the Chinese migrant economy entered a second stage, that of rapid growth and multiplication. Despite the impact of the 1998 financial crisis in Europe, China's own market weathered the damage and indeed kept growing. This continuous growth provided important fuel for those Chinese entrepreneurs who were dependent on China's market. In August 2007, Europe Times (the Chinese journal in 
France) published a report describing such a pattern: "From Sweden and England to Spain and Italy, the whole Europe is witnessing the multiplication of Chinese commercial centers." In France, at Aubervilliers, the CIFA ${ }^{2}$ market has expanded to become the largest Chinese wholesale center in Europe, with 40,000 square meters and more than 300 wholesale shops. In Germany, Chinese markets have spread throughout the country: from Leipzig to Dusseldorf, Hamburg to Munich, more than 20 wholesale shops and markets have spread in these and other cities. In Berlin and Frankfurt, we even find more than one Chinese wholesale center co-existing in the same city. In Prato, Italy, more than 100 wholesale shops of jewelry and ready-to-wear items will be lodged in a Chinese mall, the first wholesale center owned by ethnic Chinese investors. In Kalmar, Sweden, the construction of a Chinese center began in February 2013. Finally, the Marco Polo Commercial Center, with 150,000 square meters, is the biggest commercial center in Italy. The center's investors chose to hold the inauguration ceremony for the mall at the Great Hall of the People in Beijing, making it the most representative case of the Chinese malls in Europe.

Meanwhile, the Chinese economy contributed considerably to the economic revival of Eastern Europe. In Russia, new Chinese migrants represent the main economic pillar of various market places. They serve as an important force in the trading flows between China and Russia. In Belgrade, Serbia, the "No. 70" wholesale market is extremely prosperous, offering a range of commodities from needles to materials for interior decor. Finally, it is worth noting the examples of the Ostrava wholesale market in Czech and both the Red Dragon and the 7 Kilometer market in Odessa, Ukraine. Their expansion also includes renovation and construction of new markets.

After the 2008 financial crisis in Europe, recession in Europe impelled the Chinese migrants' economy to a period of transition. The third phase of the Chinese migrant economy is thus marked by adaptation and transition during these challenging times. By this point, the Chinese mall economy had developed to the point that markets paid more attention to issues of environment, hygiene and cleanliness; at the same time, the entrepreneurs involved also sought to innovate. Moreover, the Chinese mall's spatial concentration began to produce some negative social impacts. Problems engendered by the Chinese entrepreneurs' activities are potentially highlighted by their host country's media, and might even provoke diplomatic troubles between China and the host country.

\section{A Typology of Chinese malls in Europe}

Table 1. Chinese malls in Europe

\begin{tabular}{|l|l|l|l|l|}
\hline Country & City & Market Place & Construction Type & Investors \\
\hline \multirow{2}{*}{ France } & Paris & Popincourt & $\begin{array}{l}\text { Neighborhood } \\
\text { concentration in city } \\
\text { center }\end{array}$ & Individual Chinese wholesalers \\
\cline { 2 - 6 } & & CIFA & $\begin{array}{l}\text { Newly constructed } \\
\text { mall }\end{array}$ & French real-estate company \\
\cline { 2 - 5 } & Aubervilliers & & &
\end{tabular}




\begin{tabular}{|c|c|c|c|c|}
\hline & & Fashion Centre & $\begin{array}{l}\text { Newly constructed } \\
\text { mall }\end{array}$ & Chinese entrepreneurs \\
\hline Italy & Roma & Piazza Vittorio & $\begin{array}{l}\text { Neighborhood } \\
\text { concentration }\end{array}$ & Chinese entrepreneurs \\
\hline Spain & Madrid & Fuenlabrada & $\begin{array}{l}\text { Recycling of } \\
\text { industrial wasteland }\end{array}$ & Chinese entrepreneurs \\
\hline \multirow{5}{*}{ Russia } & \multirow{5}{*}{ Moscow } & $\begin{array}{l}\text { Cherkízovsky } \\
\text { rýnok }\end{array}$ & Open-air market & Local market owner \\
\hline & & Luniki Stadium & Outdoor market & \\
\hline & & $\begin{array}{l}\text { Central Dynamo } \\
\text { Stadium }\end{array}$ & Outdoor market & \\
\hline & & Greenwood Park & $\begin{array}{l}\text { Newly constructed } \\
\text { commercial center }\end{array}$ & $\begin{array}{l}\text { Joint venture between Chinese } \\
\text { enterprise (Group Hengtong) } \\
\text { and Moscow city hall }\end{array}$ \\
\hline & & $\begin{array}{l}\text { Yiwu } \\
\text { international } \\
\text { trading center }\end{array}$ & $\begin{array}{l}\text { Newly constructed } \\
\text { commercial center }\end{array}$ & $\begin{array}{l}\text { Joint venture between private } \\
\text { Chinese groups and a Russian } \\
\text { enterprise }\end{array}$ \\
\hline \multirow[b]{2}{*}{ Romania } & Bucharest & Niro market & Open-air market & Local owner \\
\hline & Bucharest & $\begin{array}{ll}\text { Red } & \text { Dragon } \\
\text { Market } & \end{array}$ & $\begin{array}{l}\text { Newly constructed } \\
\text { center }\end{array}$ & Chinese entrepreneurs \\
\hline
\end{tabular}

12 The most important Chinese wholesale centers in Europe currently include Aubervilliers, Popincourt in Paris 19th, and Piazza Victtorio in Rome; as well as the warehouse area near Rome airport, Fuenlabrada in Madrid, Eurosquare and the Wenzhou and Monori centers in Budapest, the Red Dragon market in Romania, and the Monori center in Moscow. As the economic environments differs between Eastern and Western Europe, the Chinese mall's development processes are different. All in all, we can define three different development paths of Chinese wholesale markets, characterized by their type of construction.

The first type is the open-air market. These markets often stem from a spatial concentration of Chinese entrepreneurs. These markets are mainly situated in Eastern Europe, especially in Russia. In the early 1990s, in Moscow, hundreds of open-air markets of different sizes appeared at various subway stations - and even beside national stadiums (Luniki Stadium, Central Dynamo Stadium) - thus constituting a widespread commercial network of lower and middle-range commodities. These markets are popular to entrepreneurs because of their low entry threshold and simple business model. Before September 2008, the local Chinese in Moscow used to refer to the Cherkizovsky rýnok as the "Big Ant market," and it has since expanded to cover hundreds of hectares in Moscow. Although these markets are most often austere and unassuming - many so-called "shops" are simply abandoned containers - the daily transactions in the "ant market" can reach 50 to 60 million USD, with tens of thousands 
of Chinese living and working within. Another example of this kind of market is the "Huge Chinese market" in the city of Yekaterinburg, Siberia. The huge market is spread over 40,000 square meters, where the made-in-China textile products represent $95 \%$ of the local market. Of the 60,000 shops, more than $90 \%$ are Chinese. The shops are mere tin sheds and the commodities sold here are almost exclusively made in China.

The second type of development path is seen in neighborhoods with a highly concentrated Chinese market. In the 11th arrondissement of Paris, a market was formed by traders who were principally overseas Chinese from some of the former asian French Colonies (Laos, Cambodia) and Indonesia; despite this, the neighborhood's image is that of a traditional Chinatown, with Chinese-owned supermarkets, restaurants, travel agencies and beauty salons. This kind of neighborhood can be found in England (London and Manchester), Netherlands (Rotterdam and Amsterdam) and Spain (Madrid). Here, our study focuses on another type of economy. Whereas earlier market models were based on retail, the Chinese malls - concentrated mainly in a single neighborhood-rely on wholesale trading. Their commodities are highly concentrated (textiles or bags), especially intended for retailers themselves. The Chinese wholesale market in Europe is further characterized by its sector specializations in textile, electronic and toys. The flows of customers, traffic, commodities and capital involved in wholesale trading are of a far greater magnitude than those affecting traditional Chinatown shop owners. In this sense, the two kinds of neighborhoods are not comparable. It is a matter of scale: in Madrid, for example, more than 300 wholesale shops and 3,000 small shops are concentrated at the Chinese market at Fuenlabrada. In Paris, in the 11th arrondissement of Paris, there are 40 wholesale shops on Rue Popincourt, where there used to be 50 commercial shops. In Italy, in a neighborhood near Piazza Vittorio in Roma, more than 500 wholesale shops belonging to Chinese entrepreneurs are spread among several avenues traversing the neighborhood.

15 The third type of development path involves the renovation of old warehouses or factories - or the construction of new facilities altogether - which are then divided or rented to wholesale entrepreneurs. This is especially the case at Aubervilliers, which was a defunct industrial neighborhood before the 1990s. Today, it has become a commercial hub supporting almost a thousand wholesale shops. The Red Dragon market in Romania and the Greenwood International Trading Center in Moscow are also examples of such an approach to development.

\section{The investors of the Chinese markets in Europe}

16 An unprecedented economic model in Europe, managed by immigrant entrepreneurs, the Chinese trading market is an economic pillar for European Chinese migrants, a platform of circulation of trading between China and Europe, and an infrastructure for the global trading network of made-in-China products. Investors in Chinese malls in Europe generally include five types of actors: non-Chinese entrepreneurs from the local society, Chinese migrant entrepreneurs living in Europe, entrepreneurs of other minorities in the local society, entrepreneurs from China, and Chinese state enterprises. There are various types of coalition between these investors: sometimes they work together, sometimes alone. Both conflict and collaboration occur. In the past two or three years, a new trend has emerged: some well-off Chinese entrepreneurs and 
enterprises have come to consider the real estate as a profitable item of investment, and are spending thusly. The most remarkable example is the Fashion center in Aubervilliers, an outskirt of northern Paris. During the 1970s Aubervilliers experienced a process of deindustrialization, as numerous enterprises left the city and invested in countries outside France. At this moment, a group of Jewish entrepreneurs saw a business opportunity: they purchased the abandoned factories, renovated the old warehouses into showrooms, and rented them to Jewish wholesalers. In the 1990s, some Chinese entrepreneurs were attracted by this pre-existing wholesale infrastructure and set up their own shops there. As the number of Chinese wholesalers increased, the Jewish entrepreneurs, principal landlords of the real estate, profited.

The development of the Chinese wholesalers' community in Aubervilliers continues to attract the attention of real estate promoters. In October 2006, French real estate companies invested tremendous capital to establish a "customized" wholesale center named "CIFA". The first wave of the construction included 95 shops among 15,000 $\mathrm{m}^{2}$, each between 110 and $400 \mathrm{~m}^{2}$. The CIFA proposition occurred in the golden age of the Aubervilliers wholesale market: even before the center's inauguration, its shops were already sold out. One year later, the company proposed CIFA's second phase. In 2012, in the shadow of a global financial crisis, eight Chinese entrepreneurs collaborated in a new 1 billion euros construction project: the "Fashion Center", also located in Aubervilliers. With a total surface area of around $5,500 \mathrm{~m}^{2}$, the development will contain more than 300 wholesale shops and provide more than 2,800 jobs, with estimated financial flows up to 4.5 million euros.

In Bucharest, from the "Europa center" to the Red Dragon Market, much of the real estate was owned by local Romanians. According to the local Chinese community leaders interviewed, the two Chinese markets were owned by Niro, a local company held by Romanian investors. In order to gain higher profit, the Niro company continually modified their rental strategy and even forced the Chinese wholesalers to rent new shops. Under such circumstances, the Chinese wholesalers in Romania organized the "Tangrenjie Realestate Group" (literally meaning "Chinatown") and collaborated with a Turkey-based company that held land in Bucharest. They invested about 1 billion euros and constructed a $250,000 \mathrm{~m}^{2}$ wholesale market, able to host more than 200 wholesale shops. Unfortunately, as the center was developed at the moment of the European debt crisis, the economic conditions were not beneficial for the Chinese enterprises. This structural situation was worsened by internal conflict between the Tangrenjie investors, and the final economic returns were not ideal.

Moscow's biggest project is the Greenwood Commercial Center, which was mainly financed by the Hengtong Group. Located in the north of Moscow and inaugurated on 16 September 2012, the Greenwood center is arrayed over 20 hectors of land. According to Greenwood's presentation, the objective of the development was to establish an efficient platform for economic collaboration between China and Russia, a platform aligning with the Chinese government's program which aimed to support the marketization of its economy and to promote structural improvements for overseas Chinese entrepreneurs. A similar project, also in Moscow, is the Yiwu International Trading Center, whose investors included the Zhejiang-based Shifeng company, the city government of Moscow, and the Russian group Tashir. Their combined investment amounted to 5 billion US dollars. With a $40 \%$ share, the Moscow city government is the most prominent of the investors; the project represents the most expensive project the 
city has invested in. Upon construction, the center will be able to host more than 1,900 shops, all dedicated to the sale of made-in-China products ${ }^{3}$.

\section{The characteristics of Chinese mall economy in Europe}

Common characteristics of the Chinese migrant economy in Europe include small shops, extensive stocks, low barriers to entry, and large agglomeration economies. The malls' spatial concentration of shops attracts a large number of customers, reinforcing their popularity and reputation. Moreover, the Chinese market also serves as a platform for the flow of information, which allows individual entrepreneurs to acquire knowledge efficiently. As a result, enterprises in the same sector can easily achieve consistency, thus enlarging the whole commercial sector.

Most countries in Western Europe are welfare states with systems of high taxes. The market for local brands is already stable, and tend to lack products in the middle or lower end. The Chinese market is based mainly on low-end products imported from China. Its model of management is more or less characterized by informal practices: some retail shop owners maintain a relationship with wholesalers based on trust, taking products before payment; some wholesalers take orders from prominent local companies. Other practices situated in this "grey zone" include "grey declarations" (huise qinguan), overworking, etc. No matter their strategy, these practices generally create advantages over local entrepreneurs.

Seen positively, the Chinese market is composed of low and middle-end products that complement the high-end products already existing in the local market. The wholesale sectors' clients are mainly composed of other entrepreneurs who are also immigrants. In this sense, the local society's lower and middle classes benefit directly from the wholesale business. On the other hand, it may be said that the Chinese market does not necessarily eclipse the model of the open-air market. Most shops are still based on the "family workshop" model that relies on family relationships and maximizes profits through informal channels.

The informal economy takes advantage of the formal economy's blind spots. Those "shortcuts" tend to allow the market to circumvent legal control. Legal inspection may not be considered a priority when the European economy is running well; however, in times of financial crisis, European governments tend to strengthen their control in order to increase revenue. After the financial crisis in 2008, the economy in Europe experienced a decline, and a heated debate arose in a context of economic disagreements and ethnic hostilities. As a result, the Chinese malls also became a target for critics and regulators.

\section{The social and security problems faced by Chinese malls}

[We have decided not to translate this section because it is less pertinent to the concern of the special issue] 


\section{Perspectives of European wholesale markets} and integration plans. The European welfare system is based on high taxes; while Chinese entrepreneurs take advantage of local systems of social protection, they should also be conscious of their social responsibility to create wealth for local societies and populations. A minority group that positively creates employment opportunities and taxable income for its host society can necessarily win the respect and recognition of local governments and citizens, creating solidarity between their host society and their 
home country. It is necessary for Chinese wholesalers to normalize their business practices with respect to the mainstream law, thus improving their image in the process.

\section{NOTES}

1. On the evolution and development of overseas Chinese communities in Europe, see Li Minghuan 2002, Ouzhou Huaqiao Huaren Shi (History of Overseas Chinese in Europe.) Zhongguo huaqiao chuban she. On the structural change of Chinese communities since the $21^{\text {st }}$ century, see Li Minghuan, 2009 "Ouzhou huaren shehui poxi" ("Analysis of Overseas Chinese communities in Europe"), Shijie Minzu 2009: 5.

2. Centre international France-Asie (International France-Asia Center).

3. Both construction projects were initiated before the 2008 economic crisis. The two malls were built during the crisis and were inaugurated during the period when the crisis deepened. As the existing wholesale market faced decline due to the crisis, the proposition of several hundred new wholesale shops seemed destined to fail. As of this article's writing, many showrooms in the two malls are not yet rented. Furthermore, the two malls very much resemble one another in terms of architectural design and business model. As a result, the competition is even more brutal. It is important for the malls' investors and managers to find out solutions for a healthier competition.

\section{ABSTRACTS}

Starting at the turn of the 21st century, Chinese shopping centres have rapidly developed in Europe's major cities. Be it Paris, Rome, Madrid or Moscow, these centres, through the spatial concentration of shops, have become one of the modalities of China's presence abroad. This article retraces the historical and social contect that has contributed to the development of Chinese shopping centres in Europe. It then offers a typology of these centres according to their characterisitics. Finally, it outlines the social challenges and problems facing these centres in the European context during the aftermath of the 2008 economic crisis.

Depuis le XXI ${ }^{\mathrm{e}}$ siècle, les centres commerciaux chinois se sont rapidement développés dans les métropoles européennes. Que ce soit à Paris, Rome, Madrid ou Moscou, les centres commerciaux sont devenus une des modalités de la présence de la Chine à l'étranger, à travers la concentration spatiale de magasins. Ce papier retrace le contexte historique et social qui a contribué à la formation de centres commerciaux chinois en Europe. Il propose ensuite une typologie de ces centres commerciaux selon leurs caractéristiques. Enfin, il conclut par les défis et les problèmes sociaux auxquels sont confrontés ces centres commerciaux dans le contexte européen de l'aprèscrise économique de 2008. 
Los centros comerciales chinos se han desarrollado rápidamente en las metrópolis europeas desde inicios del siglo XXI. Su creciente concentración espacial en París, Roma, Madrid o Moscú visibilizan la presencia de China en el exterior. Este artículo propone una categorización de esta tipología comercial en Europa y explica el contexto histórico y social que ha favorecido su formación. Por otra parte, señala los desafíos y conflictos a los cuales se enfrenta este modelo de actividad en Europa después de la Gran Recesión de 2008.

\section{INDEX}

Mots-clés: centres commerciaux chinois, Chinois d'outre-mer en Europe, commerce ChineEurope

Subjects: Les routes de la soie existent déjà. Routes transnationales et places marchandes du made in China entre Asie Afrique et Europe

Palabras claves: centros comerciales chinos, Chinos de ultramar en Europa, intercambio comercial China-Europa

Keywords: chinese malls, overseas Chinese in Europe, chinese-european trade 